Aworinde Olalekan Bashir ${ }^{1}$, Yinusa Olumuyiwa Ganiyu², Williams Tolulope Oyakhilome ${ }^{3}$

\title{
MACROECONOMIC POLICIES AND \\ THE AGRICULTURAL SECTOR IN NIGERIA: EVIDENCE FROM ASYMMETRIC COINTEGRATION
}

This study examines the impact of macroeconomic policies on Agricultural output in Nigeria using the Asymmetric cointegration estimator. The results of the study showed that interest rate, inflation and exchange rate are important monetary policy variables driving the performance of agricultural sector in Nigeria. In addition, from the fiscal angle, the study found that budgetary provision for the agricultural sector over the years in Nigeria have been abysmally low and not up to the $10 \%$ of total budget specified in the Maputo (2003) declaration, although agricultural budgetary allocation has a positive and significant relation with agricultural output. Similarly, the study found that institutional quality propels growth of the agricultural sector in Nigeria, but statistically insignificant. The study therefore concludes that macroeconomic policies (monetary and fiscal) apart from institutional quality are crucial variables that influence the performance of agricultural sector in Nigeria, as a results government need to align properly both the monetary and fiscal variables to achieve better agricultural performance while not overlooking the role of institutional quality.

Keywords: Macroeconomic policies, Agricultural performance, Maputo, institutional quality.

JEL Classification: E10, Q00, Q10

For. 10. Fig. 3. Tab. 5. Lit. 41.

Peer-reviewed, approved and placed: 12.01.2020.

DOI: $10.32752 / 1993-6788-2020-1-223-25-41$

\section{Аворінде Олалекан Башир, Інуса Олумуїва Ганію, Вільямс Толулопа Ояхіломе \\ МАКРОЕКОНОМІЧНА ПОЛІТИКА ТА АГРАРНИЙ СЕКТОР НІГЕРІЇ: ДОКАЗИ АСИМЕТРИЧНОЇ КОІНТЕГРАЦІЇ}

У цьому дослідженні вивчається вплив макроекономічної політики на сільськогосподарське виробництво в Нігерії за допомогою оцінювача асиметричної коінтеграції. Результати дослідження показали, що процентна ставка, інфляція та обмінний курс с важсливими змінними грошово-кредитної політики, що визначають результати діяльності аграрного сектору в Нігерії. Крім того, з фіскального боку, дослідження показало, що бюджетні забезпечення сільськогосподарського сектору протягом багатьох років у Нігерії були безмежно низькими і не досягали $10 \%$ від загального бюджету, зазначеного в декларації Мапуто (2003), хоча розподіл бюджету на сільське господарство має позитивне $і$ значне відношення до продукції сільського господарства. Подібним иином дослідження показало, що інституційна якість сприяє зростанню сільськогосподарського сектору в Нігерї̈, але статистично незначна. Тому дослідження робить висновок, що макроекономічна політика (грошово-кредитна та фіскальна), крім інституційної якості, є вирішальними змінними, що впливають на ефективність сільськогосподарського сектору в Нігерії, оскільки в результаті уряд повинен правильно узгодити як грошово-кредитну, так і фіскальну величини, щоб досягти кращих показників сільського господарства, а не не зважсаючи на роль інституційної якості.

\footnotetext{
${ }_{1}^{1}$ Pan Atlantic University, Lekki Lagos, Nigeria

${ }_{3}^{2}$ Olabisi Onabanjo University, Ago-Iwoye, Ogun state, Nigeria.

${ }^{3}$ Olabisi Onabanjo University, Ago-Iwoye, Ogun state, Nigeria.
}

ORCID: 0000-0002-2642-5790 
Ключові слова: макроекономічна політика, ефективність сільського господарства, Мапуто, інституційна якість.

\section{Аворинде Олалекан Башир, Инуса Олумуива Ганию, Уильямс Толулопа Ояхиломе \\ МАКРОЭКОНОМИЧЕСКАЯ ПОЛИТИКА \\ И АГРАРНЫЙ СЕКТОР НИГЕРИИ: ДОКАЗАТЕЛЬСТВА АСИММЕТРИЧНОЙ КОИНТЕГРАЦИИ}

В этом исследовании изучается влияние макроэкономической политики на сельскохозяйственное производство в Нигерии с помощью оценщика асимметричной коинтеграции. Результаты исследования показали, ито процентная ставка, инфляция и обменный курс важны сменными денежно-кредитной политики, определяющие результаты деятельности аграрного сектора в Нигерии. Кроме того, из фискального стороны, исследование показало, ито бюджетные обеспечения сельскохозяйственного сектора в течение многих лет в Нигерии были безмерно низкими и не достигали $10 \%$ от общего бюджета, указанного в декларации Мапуту (2003), хотя распределение бюджета на сельское хозяйство имеет положстельное и значительное отночение к продукции сельского хозяйства. Подобным образом исследование показало, ито институциональная качество способствует росту сельскохозяйственного сектора в Нигерии, но статистически незначительна. Поэтому исследования делает вывод, что макроэкономическая политика (денежно-кредитная и фискальная), кроме институционального качества, являются решающими переменными, влияющих на эффективность сельскохозяйственного сектора в Нигерии, поскольку в результате правительство должно правильно согласовать как денежно-кредитную, так $и$ фискальную величины, чтобы достичь лучших показателей сельского хозяйства, а не упуская из виду роль институционального качества.

Ключевые слова: макроэкономическая политика, эффективность сельского хозяйства, Мапуту, институциональная качество.

1. Introduction. Nearly 800 million people suffer from hunger globally and the vast majority of them live in developing countries (United Nations, 2015). These figures motivate the inclusion of zero hunger, defined as the eradication of hunger and the achievement of food security, as a Sustainable Development Goal (SDG) in the United Nations (UN) Sustainable Development Agenda and feeding of Africa as one of the High 5s (five) of the African Development Bank Agenda. To achieve the sustainable development goals and the goal of feeding Africa for the developing countries there is the need to reinvigorate the agricultural sector of developing countries. The Agriculture sector in most developing countries is largely underdeveloped and relies on primitive tools as against mechanized Agriculture, output per hectare is still very low, access to capital and credit by farmers is very limited and at very high cost, basic amenities and infrastructure that can enhance Agricultural performance is minimal and of very poor quality. Despite these challenges, Agriculture remains very key to the development of Nigeria. Agriculture still employs 60 per cent of the total labour force in Nigeria (Adeoti, 2002). The growth rate of the contribution of the agricultural sector stood around 7.2 per cent in 2006 as against 4.2 per cent in 2002 but rose to 5.53 per cent in 2014 but reduced to 4.53 per cent in 2016 during the recent economic recession. 
The current federal government in Nigeria made agriculture one of its pillars of growth and job creation as contained in the Economic Recovery and Growth Plan (ERGP).The Economic Recovery and Growth Plan (ERGP) recognized agriculture as one of the six priority sectors. The goal of the current Federal government is the creations of Agricultural programs that can ensure Nigeria grow what Nigerian eats. But to what extent has the government provided and plan to realize this goal through the Agricultural sector. thus, the need to assess extent to which government budgetary allocation (fiscal spending) align with government policy direction and conform with the Maputo (2003) declaration that African countries should commit 10 per cent of their budgetary allocation on agriculture and rural development with an effort to increase agricultural production, reduce hunger and have food security. Prior to this agreement, most countries in Africa including Nigeria do import food as a result of the low agricultural output. When countries engage in importation of food a lot of foreign exchange earnings would be lost and consequently affect food prices as well as the standard of living of the people.

It is important for Nigeria to commit to the Maputo declaration because the development of the agriculture sector in Nigeria is the gateway to industrialization and as such the Nigeria case is somewhat peculiar because it cannot be compared to emerging economies that started from low-to-medium technologies to advanced technology. This is because such economies have the required infrastructure such as constant electricity supply among others to develop her economy. For, the case of Nigeria, there is the need develop the agricultural sector first, rather than concentrate on sectors where they can export high value added technology and import value added agriculture. This is because institutions and infrastructure that will culminate into gains from trade is not in place. Thus, there is the need for the Nigerian government to key into the Maputo declaration to achieve food sufficiency and also to grow the manufacturing sector which requires agricultural output as their raw materials.

Apart from the issue of budgetary allocation, which captures the fiscal side in the macroeconomic equation, the role of monetary policy in agriculture sector development in Nigeria also require urgent evaluation particularly with the high cost of credit which may be attributable to high level of interest rate, inflation and exchange rate.

Several studies have examined separately the link between fiscal policy and agricultural sector output (Alesina, Ardagna, Perotti, Schiantarelli, 2002; Benetrix \& Lane 2009; Alagh, 2011; Zhllima, Imami, Kachelein \& Merkay 2013; Wesselbaum, 2014) while a number of other studies have investigated how monetary policy affects agricultural output. Among the pioneer studies in this regard include the works of Schuh, 1974; Shei, 1978; Tweten, 1980; Barnett et al, 1981; Chambers and Just, 1982; Starleaf, 1982; Bessler, 1984; Chambers, 1984; Devadoss et al, 1985; Orden, 1986; Barbhart, 1989; Orden and Fackler, 1989; Dushmanitch and Darroch, 1990 ; Kargbo ,2009; Asfaha and Jooste, 2007; Akbar and Jamil 2012; Muroyiwa, Sitima, Sibanda \& Mushunje, 2014. More recent studies include the works of Ginn and Poroy (2018) on optimal monetary policy and food subsidies and the latest work by Tule, Salisu and Chimete (2019) on predictability of agricultural commodity prices using headline inflation in Nigeria. Many scholars have investigated the relationship between macroeconomic variables and agricultural trade, but there is little literature available on the subject of macroeconomic variables specifically fiscal and monetary 
variables on agricultural output relationships in Nigeria. The examination of the direct effect of macroeconomic variables on agricultural sector output in Nigeria has thus far received little attention. The findings of the various past studies have been mixed and inconclusive and they failed to examine jointly the impact of monetary and fiscal policies as macroeconomic policies that affect agricultural output in Nigeria. The previous studies were focused on either monetary policy or fiscal policy but considering the strong linkage between monetary and fiscal policy and expected alignment between them, it becomes expedient to examine the link between fiscal and monetary policy jointly on agricultural output particularly in a country like Nigeria that is considering the development of Agriculture such that it becomes the main stay and huge source of export revenue for the government. This remains the important gap that this paper addressed by examining the effect of macroeconomic policies on Nigeria agricultural output by providing answers to the following research questions: What is the role of the Maputo (2003) declaration on Nigeria agricultural output and how well aligned is the budget with government policy direction? What is the impact of agricultural budgetary allocation, inflation rate, exchange rate, interest rate as core fiscal and monetary policies on agricultural output in Nigeria? What impact had quality governance on the Nigerian agricultural growth and what lessons can be learnt from these experiences about the future role of agriculture in the development process? In order to provide answers to the research questions raised, the paper employs the asymmetric cointegration estimators unlike previous studies in the literature that have used the symmetric cointegration estimators overlooking the role of asymmetries in the economy. Apart from the introduction, this paper is further divided into four other sections. Section two dwells on the review of literature. Section discusses the Maputo declaration of 2003 in Africa and specifically in Nigeria. Section four centres on the methodology of the study. Data, results and discussion of findings is presented in section five while section six provides the concluding remarks and recommendations.

2. Brief Review of Literature. Many scholars have investigated the relationship between macroeconomic variables and agricultural trade, but there is little literature available on the subject of macroeconomic variables specifically fiscal and monetary variables on agricultural output relationships in Nigeria. The direct effect of macroeconomic variables on agricultural sector output in Nigeria has thus far received little attention. The plethora of studies conducted in other countries especially the developed economies has documented mixed findings.

The various findings from the studies have not reached a consensus on the various monetary and fiscal variables that drive Agricultural output. A study by Kargbo (2009) examined the effects of macroeconomic factors on agriculture in South Africa and provides evidence that expansionary monetary policy favours agriculture in the short run. Specifically, interest rates, inflation and money supply have significant impacts on agricultural product and input prices. This finding is similar to the findings of (Townsend 1997, Ivanova, Dawson \& Lingard 2003) that identified that a cointegration relationship exists between macro-economic variables and agricultural prices; they provide proof that interest rates shocks have large positive impacts on agricultural prices by significantly increasing farm cost and cost of short run and long run credit. Also Dewen and Fang 2004 identified that macroeconomic policy such as 
industrialization, urbanization, rural taxes, agricultural trade conditions, and liberalization policies are external conditions that influence farmer income growth.

Furthermore, other strands of studies have also examined the effect of monetary policy, specifically, effect of exchange rate on agricultural sector, for example Baek and Koo (2008) studied the relationships between short run and long run agricultural trade balance, macroeconomic aggregates and agricultural variables in United States of America and revealed that exchange rate, agricultural price and disposable income are weak exogenous variables in the USA agricultural sector, but have a significant effect on agricultural trade balance. Other studies include the work of Fadeyi, Ogundeji and Willemse (2014) showed that farm prices and agricultural exports in South Africa are affected by fluctuations in exchange rate. Earlier studies on Tunisia by Chebbi and Olarrega (2011) revealed contrary finding and identified that the impact of exchange rate depreciation in Tunisia is ambiguous on agriculture sector. A recent study by Ginn and Poroy (2018) on the effect of optimal monetary policy in the presence of food subsidies employed the dynamic stochastic general equilibrium model (DSGE). The study documented that in the presence of credit constrained households and households with a significant share of food expenditures, a coordinated reaction of fiscal and monetary policies via subsidized price targeting can improve aggregate welfare. Subsidies smooth prices and consumption, especially for credit constrained households, which can consequently result in an interest rate reaction less intensely with subsidized price targeting compared with headline price targeting. A more recent study by Tule, Salisu and Chimeke (2019) examines the predictability of agricultural commodity prices in Nigeria's inflation forecast using twelve major agricultural commodities. The study employed the Westerlund and Narayan (2015) estimator and the recursive (expanded) window approach. The results revealed that agricultural commodities individually predict both headline and food inflation better than the random walk model which is the benchmark model for forecasting inflation.

The various studies have employed different methodologies and estimation techniques ranging from the cointegration, error correction method, panel data regression estimation, dynamic stochastic general equilibrium model among other estimation methods. But none of the studies employed the asymmetric cointegration methodology in the study of the link between macroeconomic policies and Agricultural output within the framework of quality governance. This is an important gap addressed by this study.

3. Maputo Declaration and Africa. In Figure 1, it was observed that majority of the countries who are parties to the Maputo declaration of 2003, majority of the countries budgetary allocation to agriculture are less than 10 per cent. It is only Burkina-Faso, Niger, Mali, Malawi and Ethiopia that adhered to the declaration. However, there was a far cry from the Maputo declaration for other Africa countries. It is only Senegal and Zambia that is very close. On the average for the period 20002010, Nigeria agricultural budgetary allocation is around 2 per cent.

3.1.Maputo Declaration and Nigeria. With the Maputo (2003) declaration that African countries should allocate 10 per cent of their annual total expenditure to agriculture so as to alleviate poverty, reduce hunger and increase employment generation, the Nigeria's government has allocated less than 2.1 per cent on the average for the 
period 2003-2018. It is only in 2008 and 2009 that the government allocated 5.41 and 5.38 per cent respectively. In, 2015, the government allocated less than 1 per cent of her total budgetary allocation to the agricultural sector.

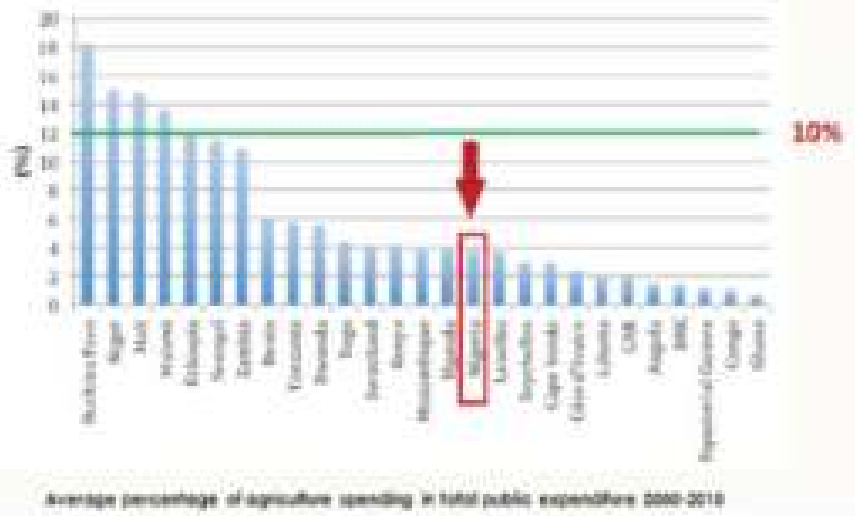

Fig. 1. Maputo Declaration \& Africa, author's

This suggests that the Nigeria government are only interested in lip service without adhering to the Maputo declaration and that the budgetary allocation to agriculture have not aligned with the Maputo (2003) policy direction.

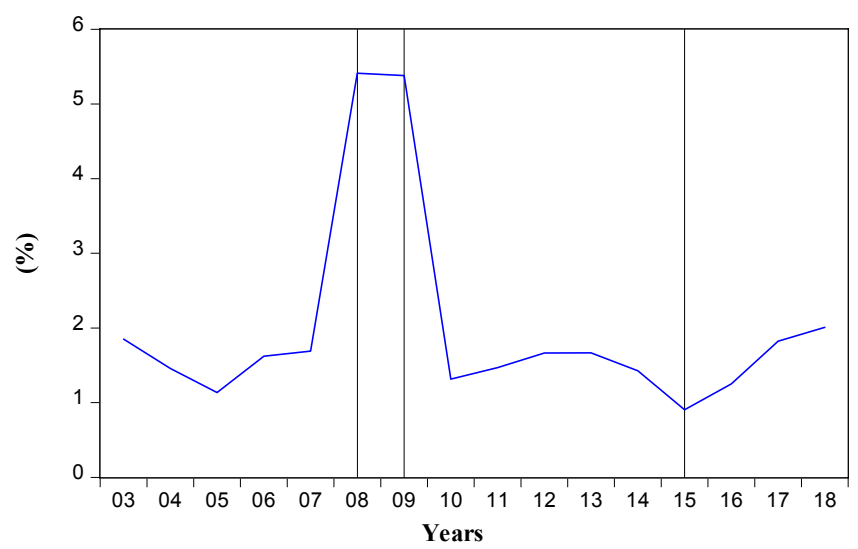

Fig. 2. Percentage of Agricultural Budgetary Allocation to National Budgetary Allocation (2003-2018), author's

3.2.The Role of Maputo (2003) Declaration on Nigeria Agricultural Output. Although, the Nigerian government have not aligned with the Maputo (2003) declaration that total agricultural budgetary allocation should be 10 per cent of her total annual expenditure. Right from the inception of the declaration, the Nigeria budgetary allocation has been 2.01 per cent on the average. Despite, the low budgetary allocation, agricultural output has been on the increase over the years despite the staggered budgetary allocation. Thus, if government efforts are geared towards the implementation of the Maputo (2003) in Nigeria, there is the tendency for more agricul- 
tural output growth which will guarantee food security and possibly eliminate hunger. Asides from food security and elimination of hunger it will lead to increase in importation of value added in agriculture thereby creating more foreign earnings to the government

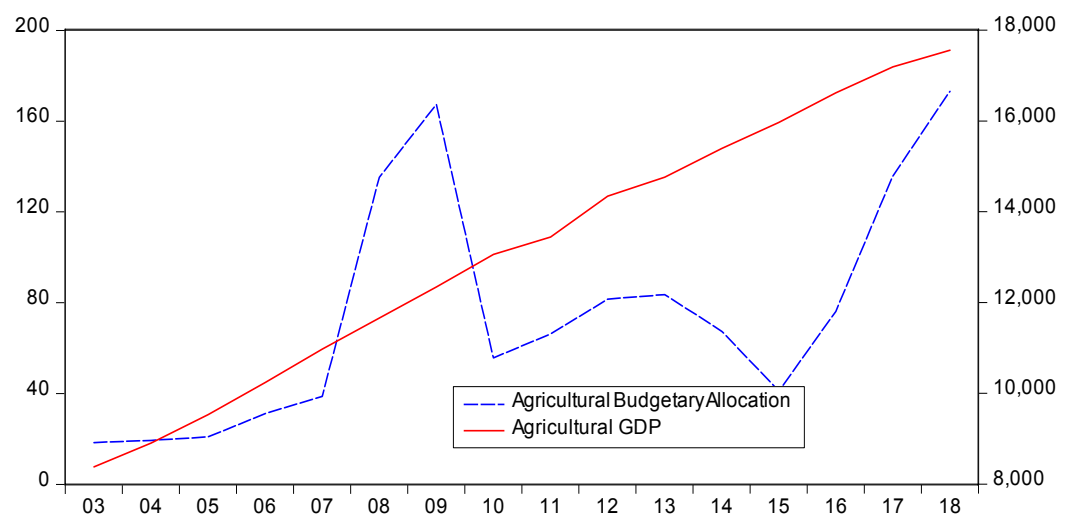

Fig. 3. Co-movement between agricultural budgetary allocation and agricultural GDP, author's

The solid line (right scale) is the agricultural GDP and the dotted line (left scale) is the agricultural budgetary allocation.

\section{Methodology}

4.1. The Unit Root Tests. The study begins the analysis, by testing for the order of integration of the variables using the Augmented Dickey-Fuller ADF (1979), the Phillips and Perron PP (1988) and Ng-Perron NP (2001) which test the null hypothesis of a unit root. A major drawback of this approach is that it does not account for the presence of structural breaks and that the series might be level stationary instead of first difference, thus rejecting the null hypothesis wrongly. To account for the wrongly rejection of the null hypothesis and to take care of structural breaks, the LM test of Lee and Strazicich (2003) which endogenously determines structural breaks is used. This test addresses the problems of bias and spurious rejections which other tests are criticized of. In addition, the tests correspond to Perron's (1989) exogenous structural break with a change in the level and the trend. Lee and Strazicich's (2003) model allows for two endogenous breaks both under the null and the alternative hypothesis. In the LM test of Lee and Strazicich (2003) demonstrate that the two-break minimum LM test has greater or comparable power to the Lumsdaine-Papell, LP, Test, thus accounting for it use.

4.2. Asymmetric Cointegration Tests. To examine the possibility of asymmetric adjustments in the series, the study uses the Enders and Siklos (2001) asymmetric cointegration methodology. Relationship between agricultural output and macroeconomic variables can be expressed as:

$L A G D P_{t}=\alpha_{0}+\alpha_{1} L A G R I C B A_{t}+\alpha_{2} I N T R_{t}+\alpha_{3} L E X R_{t}+\alpha_{4} I N F_{t}+\alpha_{5} I N S T_{t}+\varepsilon_{t}(1)$

where $L A G D P_{t}$ is the natural logarithm of the real GDP of the agricultural sector, $L A G R I C B A_{t}$ is the natural logarithm of agricultural budgetary allocation, LINTR is $_{t}$ 
lending interest rate, $L E X R_{t}$ is the natural logarithm of the exchange rate, $L I N F_{t}$ is consumer price index and $I N S T_{t}$ is the institutional quality. The specified model in equation (1) is tested for a long-run relationship. After estimating the model, the obtained residuals series $\varepsilon_{t}$ are subjected to a unit root test that of the form:

$$
\Delta \varepsilon_{t}=\rho \varepsilon_{t-1}+v_{t}
$$

where $\varepsilon_{t}$ is the residuals from equation (1) and assumed to be purely white noise with a zero mean and a constant variance while $v_{t}$ is anindependent and identically distributed disturbance with zero mean. If the null hypothesis of $\rho=0$ can be rejected, then $\varepsilon_{t}$ is stationary. The model in equation (2) assumes a symmetric adjustment process and, therefore, change in $\varepsilon_{t}$ is $\rho \varepsilon_{t-1}$ regardless of whether $\varepsilon_{t-1}$ is positive or negative. However, if agricultural output and macroeconomic variables shows asymmetric adjustment behaviour, therefore, the model in equation (2) is mis-specified. Enders and Siklos (2001) propose two test of asymmetries; a threshold autoregressive (TAR) and a momentum-threshold autoregressive (M-TAR) models. Following Enders and Siklos (2001) two different hypotheses can be tested. The TAR model is given as:

$$
\Delta \varepsilon_{t}=I_{t} \rho_{1} \varepsilon_{t-1}+\left(1-I_{t}\right) \rho_{2} \varepsilon_{t-1}+v_{t}
$$

where $I_{t}$ is the Heaviside indicator such that

$$
I_{t}=\left\{\begin{array}{l}
1 \text { if } \varepsilon_{t-1} \geq \tau \\
0 \text { if } \varepsilon_{t-1}<\tau
\end{array}\right\}
$$

where $\tau$ is the value of the threshold and it is endogenously determined using the Chan (1993) technique. The method arranges the values of $\varepsilon_{t}$ and $\Delta \varepsilon_{t}$ for the TAR and the M-TAR models respectively in ascending order and exclude the smallest and the largest $15 \%$, making consistent estimatewhich yields the smallest residual sum of squares over the remaining $70 \%$.

The M-TAR model takes the following form:

$$
\Delta \varepsilon_{t}=M_{t} \rho_{1} \varepsilon_{t-1}+\left(1-M_{t}\right) \rho_{2} \varepsilon_{t-1}+v_{t}
$$

where $M_{t}$ is the Heaviside indicator such that

$$
M_{t}=\left\{\begin{array}{l}
1 \text { if } \Delta \varepsilon_{t-1} \geq \tau \\
0 \text { if } \Delta \varepsilon_{t-1}<\tau
\end{array}\right\}
$$

The necessary condition for the stationarity of $\varepsilon_{t}$ is that $\rho_{1}<0, \rho_{2}<0$ and $\left(1+\rho_{1}\right)$ $\left(1+\rho_{2}\right)<1$. If $\varepsilon_{t-1}$ is above the long-run equilibrium value, thenadjustment is at the rate of $\rho_{1}$, but if $\varepsilon_{t-1}$ is below the long-run equilibriumvalue then adjustment is at the rate of $\rho_{2}$. However, adjustment is symmetric if $\rho_{1}=\rho_{2}$. Therefore, where the null hypothesis H0: $\left(\rho_{1}=\rho_{2}\right)$ is rejected, then the TAR model can be used to capture the signs of the asymmetries. The M-TAR model is useful when the adjustment exhibits more momentumin one direction than the other. That is, the speed of adjustment dependson whether $\varepsilon_{t-1}$ is increasing or decreasing. If $\left|\rho_{1}\right|<\left|\rho_{2}\right|$, then increases in $\Delta \varepsilon_{t-1}$ may tend to persist, whereas decreases revert back to the thresholdare done quickly. 
Enders and Siklos (2001) proposed two sets of tests to test the null hypothesis $\mathrm{H} 0: \rho_{1}=\rho_{2}$ in equation (5) for both the TAR and M-TAR models. The $F$ statistic does not follow the standard distribution, consequently, $\varnothing_{u}$ from the estimated TAR model is compared with $\varnothing^{*} u$ ufor the M-TAR modelprovided in Enders and Siklos (2001). Since there is no presumption whether to use TAR or M-TAR model, the recommendation is to use the information criteria to determine the better model among the two. If the residuals in equations (3) and (5) are serially correlated, they are:

$$
\begin{gathered}
\Delta \varepsilon_{t}=I_{t} \rho_{1} \varepsilon_{t-1}+\left(1-I_{t}\right) \rho_{2} \varepsilon_{t-1}+\sum_{i=1}^{P} \beta_{i} \Delta \varepsilon_{t-i}+v_{t} \\
\Delta \varepsilon_{t}=M_{t} \rho_{1} \varepsilon_{t-1}+\left(1-M_{t}\right) \rho_{2} \varepsilon_{t-1}+\sum_{i=1}^{P} \gamma_{i} \Delta \varepsilon_{t-i}+v_{t}
\end{gathered}
$$

Model in equation (7) represents the new TAR model while the one in equation (8) is the modified M-TAR model, respectively.

The asymmetric version of the error correction model (ECM) is formulated as equation (9) and (10).

$$
\begin{aligned}
& \Delta L A G D P_{t}=\rho_{11} I_{t} \hat{\varepsilon}_{t-1}+\rho_{12}\left(1-I_{t}\right) \hat{\varepsilon}_{t-1}+\sum_{i=1} \varphi_{k} \Delta L A G R I C B A_{t-i} \\
& +\sum_{i=1}^{P} \delta_{k} \Delta L E X R_{t-i}+\sum_{i=1}^{P} \eta_{k} \Delta I N T R_{t-i}+\sum_{i=1}^{P} \propto_{k} \Delta I N F R_{t-i}+\sum_{i=1}^{P} \omega_{k} \Delta I N S T_{t-i} \\
& \Delta L A G D P_{t}=\rho_{11} M_{t} \hat{\varepsilon}_{t-1}+\rho_{12}\left(1-M_{t}\right) \hat{\varepsilon}_{t-1}+\sum_{i=1}^{P} \varphi_{k} \Delta L A G R I C B A_{t-i} \\
& +\sum_{i=1}^{P} \delta_{k} \Delta L E X R_{t-i}+\sum_{i=1}^{P} \eta_{k} \Delta L I N T R_{t-i}+\sum_{i=1}^{P} \propto_{k} \Delta L I N F R_{t-i} \\
& +\sum_{i=1}^{P} \omega_{k} \Delta I N S T_{t-i}
\end{aligned}
$$

The ECM represented by the parameters $\rho_{i t}$ captures the speed of adjustments back to the equilibrium. The speed of adjustment for any positive deviation from long-run equilibrium (depending on the attractor indicator) is denoted by $\rho_{11}$. In the same vein, the of speed of adjustment of any negative deviations as defined by the attractor indicator, is known as $\rho_{12}$.

\section{Data and the Estimated Results}

5.1. Data. The data-set used in this analysis consists of annual series covering the period 1984-2018 for Nigeria. The data are as follows; agricultural output is the real 
GDP of the agricultural sector (AGDP), agricultural budgetary allocation (AGRIC$\mathrm{BA}$ ), exchange rate is defined as the average official exchange rate of the naira to the United States dollar (EXR), inflation is the consumer price index (INFR), interest rate is the lending interest rate (INTR) and institutional quality (INST) is the average of all the institutions variables namely as; average of government stability, socioeconomic conditions, investment profile, law and order, democratic accountability and bureaucracy quality. The annual data on agricultural output, agricultural budgetary allocation, exchange rate, interest rate and inflation rate comes from the Central Bank of Nigeria statistical bulletin and the institutional quality variable is sourced from the International Country Risk Guide (ICRG). The criteria for choosing the time frame are based on the data availability and the operation of the flexible exchange rate regime by the Central bank of Nigeria (Ahmad, Pentecost and Harvey 2011).

\subsection{Unit Roots Test Results}

5.2.1. ADF, PP and the NP. The results in Table 1 shows that the Augmented Dickey-Fuller ADF (1979), the Phillips and Perron PP (1988) and Ng-Perron NP (2001) which test the null hypothesis of a unit rootindicate that all the variables are non-stationary $\mathrm{I}(0)$ at levels, but stationary at first differences $\mathrm{I}(1)$, thus giving room for the estimation of long run relationship.

Table 1. Unit Root Tests, author's

\begin{tabular}{|l|c|c|c|}
\hline Variables & ADF & PP & NP \\
\hline LAGDP & -1.026 & -1.112 & -0.948 \\
\hline$\Delta$ LAGDP & -4.873 & -4.875 & -2.017 \\
\hline LAGRICBA & -1.065 & -1.381 & -1.008 \\
\hline$\Delta$ LAGRICBA & -5.854 & -6.432 & -4.044 \\
\hline INFR & -0.775 & -0.775 & -0.483 \\
\hline$\Delta$ INFR & -4.332 & -4.332 & -3.655 \\
\hline LEXR & -1.536 & -1.520 & -0.406 \\
\hline$\Delta$ LEXR & -4.142 & -4.142 & -4.095 \\
\hline INTR & -2.505 & -2.318 & -1.616 \\
\hline$\Delta$ INTR & -4.531 & -7.371 & -5.151 \\
\hline INST & -1.878 & -1.779 & -1.287 \\
\hline$\Delta$ INST & -6.506 & -6.542 & -5.013 \\
\hline
\end{tabular}

Notes: In this paper for the NP test we use the test statistic MZt. Proper lag length for each test was chosen by AIC *** and $* *$ indicates significance at the $1 \%$ and $5 \%$ levels respectively.

5.2.2. The LM Test with Structural Breaks. Following, the unit root test of ADF, PP and NP that all variables are first difference, the study examined the possibility of structural breaks in the all the series. Results from Table 2 shows that accounting for one structural break, all the series were not stationary at levels, but all the series were later stationary in their first differences. The LM test with two structural breaks suggests that inflation rate, interest rate and institutional quality were all significant at levels, whereas agricultural real GDP and exchange rate were stationary in their first differences.From the foregoing results on unit root, the study concludes that all the results were stationary in their first differences, thus giving room for the estimation of long-run symmetric cointegrating relationship. 
The identified structural break dates by the LM Test were shown to have taken place mostly between the late eighties and nineties. These periods were period of severe external shocks, institutional and structural reforms. The external shocks include oil price slumps of the 1990s and the resultant worsening in terms of trade.

Table 2. LM Tests with One and Two Structural Breaks, author's

\begin{tabular}{|l|c|l|c|c|c|c|c|c|c|}
\hline \multicolumn{1}{|c|}{ Variables } & $\mathrm{TB}$ & \multicolumn{1}{c|}{$\alpha$} & $\mathrm{k}$ & $\lambda$ & $\mathrm{TB}_{1}$ & $\mathrm{~TB}_{2}$ & $\alpha$ & $\mathrm{k}$ & $\lambda$ \\
\hline LAGDP & 2000 & -2.268 & 0 & 0.5 & 2000 & 2005 & -4.074 & 1 & $0.5,0.6$ \\
\hline$\Delta$ LAGDP & 1995 & $-5.128^{* *}$ & 0 & 0.4 & 2000 & 2003 & $-9.417^{* * *}$ & 0 & $0.5,0.6$ \\
\hline LAGRICBA & 2008 & -2.067 & 1 & 0.7 & 1996 & 2008 & -4.059 & 1 & 0.4 .0 .7 \\
\hline$\Delta$ LAGRICBA & 2009 & $-6.771^{* * *}$ & 1 & 0.7 & 1997 & 2009 & $-7.608^{* * *}$ & 1 & $0.4,0.7$ \\
\hline INFR & 1997 & -3.138 & 1 & 0.4 & 1994 & 2009 & $-5.939^{* *}$ & 1 & $0.3,0.6$ \\
\hline$\Delta$ INFR & 1995 & $-5.323^{* *}$ & 1 & 0.3 & 1996 & 2009 & $-6.089^{* *}$ & 1 & $0.4,0.6$ \\
\hline LEXR & 1998 & -3.248 & 1 & 0.4 & 1995 & 1999 & -5.176 & 1 & $0.3,0.4$ \\
\hline$\Delta$ LEXR & 2000 & $-5.596^{* *}$ & 0 & 0.5 & 1997 & 2000 & $-8.317^{* * *}$ & 0 & $0.4,0.5$ \\
\hline INTR & 1989 & -5.057 & 0 & 0.2 & 1989 & 1998 & $-6.267^{* *}$ & 0 & $0.2,0.4$ \\
\hline$\Delta$ INTR & 1990 & $-8.267^{* *}$ & 0 & 0.2 & 1988 & 1998 & $-9.065^{* * *}$ & 0 & $0.2,0.4$ \\
\hline INST & 1996 & -3.993 & 0 & 0.4 & 1993 & 2003 & $-5.623^{* *}$ & 0 & $0.3,0.6$ \\
\hline$\Delta$ INST & 1994 & $-8.137^{* * *}$ & 0 & 0.3 & 1997 & 2002 & $-9.841^{* * *}$ & 0 & $0.4,0.6$ \\
\hline
\end{tabular}

Note: $\mathrm{k}$ is the optimal number of lagged first-differenced terms included in the unit root test to correct for serial correlation. TB denotes the estimated break points. The critical values shown are come from Table 3 Panel $\mathrm{M}$ in Lee and Strazicich (2003). ${ }^{*}, * *$ and ${ }^{* * *}$ denote significant at 10, 5 and 1 per cent levels respectively.

\subsection{Results on Cointegration Tests}

5.3.1. Symmetric Cointegration Test. Symmetric cointegration test procedure, where the lag length for each country is selected using the AIC was applied to the series. The results are reported in Table 3 from which it is evident that the null of no cointegration was not rejected. The non-detection of cointegration among the series reported in Table 3 from the linear tests could be attributed to the presence of non-linearities and asymmetric adjustments of the series. Moreover, these tests generally, have low power. Failure to reject the null of no cointegration by conventional tests of cointegration in the presence of nonlinearities and structural changes are well documented in the literature. For example, see among others Ahmad and Aworinde (2016) and Balke and Fomby (1997). To address this, the paper uses the asymmetric cointegration of Enders and Siklos (2001) methodology explained in Section 4.2 and the estimated results are discussed in 5.3.2 below.

Table 3. Estimated Parameters of Long-Run Equation for Model I, author's

\begin{tabular}{|l|c|c|c|c|}
\hline \multicolumn{5}{|l|}{ Dependent Variable : LAGDP } \\
\hline Variable & Coefficient & Standard Error & $\mathrm{t}$-test & Prob \\
\hline C & 6.784 & 1.544 & $4.395^{* * *}$ & 0.000 \\
\hline LAGRICBA & 0.421 & 0.329 & 1.281 & 0.148 \\
\hline INTR & -0.316 & 0.300 & -1.053 & 0.170 \\
\hline INFR & 0.224 & 0.075 & $2.997^{* *}$ & 0.031 \\
\hline LEXR & 0.407 & 0.218 & 1.864 & 0.112 \\
\hline INST & 0.389 & 0.408 & 0.953 & 0.216 \\
\hline \hline ADF & & & $\mathbf{- 1 . 6 5 3}$ & $\mathbf{0 . 1 8 5}$ \\
\hline
\end{tabular}

Note: ***,** and * indicates significance at the $1 \%, 5 \%$ and $10 \%$ level. 
5.3.2. Asymmetric Cointegration Tests. The information criteria were used to determine whether the adjustment mechanism is best captured as a TAR or M-TAR process, while the Ljung-Box Q-statistic was used to determine whether the estimated model is free from serial correlation or otherwise. The results of the Enders and Siklos (2001) tests are reported in Table 4.

Table 4. Estimates for Asymmetric Cointegration, author's

\begin{tabular}{|c|c|c|c|}
\hline Parameters & TAR & & MTAR \\
\hline & Consistent $\left(\phi_{u}\right)$ & & Consistent $\left(\phi_{u}^{*}\right)$ \\
\hline$p_{1}$ & -0.204 & & -0.395 \\
& $(0.257)$ & & $(3.607)^{* * *}$ \\
\hline$p_{2}$ & -0.168 & & -0.213 \\
& $(1.675)$ & & $(3.184)^{* *}$ \\
\hline Tests $H_{0}: F\left(p_{1}=p_{2}=0\right)$ & $9.306^{* *}$ & & $12.065^{* *}$ \\
\hline$H_{0}: F\left(p_{1}=p_{2}\right)$ & 2.409 & & $7.015^{* *}$ \\
\hline Threshold $\tau$ & 0.118 & & 0.321 \\
\hline AIC & -32.116 & & -29.431 \\
\hline$H_{0}:$ no serial correlation $Q_{L B}(4)$ & $2.654(0.53)$ & & $1.065(0.79)$ \\
\hline
\end{tabular}

Note: Critical values are obtained from (Wane et al. 2004). ${ }^{* * *}, * *$ and $*$ signify statistical significance at the 1,5 and 10 per cent levels, respectively. The t-statistic are in parenthesis

The null hypothesis of no cointegration for both the MTAR model is rejected given that at the 5 per cent statistical significance level, the calculated $F$-statistic (12.065) is greater than the critical value (9.85) for the MTAR. The null hypothesis of symmetric conitegration under the MTAR model is also rejected at the 5 per cent statistical significance level (see column 3). This means that the MTAR model is accepted because of the evidence of asymmetric and symmetric cointegration.

In line with the a-priori expectation with respect to the stationarity of the error term, $\rho_{1}$ and $\rho_{2}$ have negative value. Also, $\left|\rho_{1}\right|>\left|\rho_{2}\right|$ in the MTAR model, this shows that the rate of correction of the disequilibrium is faster when agricultural output and macroeconomic variables are increasing, than when the rate is declining.

The asymmetric version of the error correction model (ECM) is formulated as equation (10) because cointegration among the variables has been established, in addition to the clear evidence of asymmetric adjustment under the MTAR model. The MTAR model in equation (10) describes the dynamic relationship among the variables. The result of the asymmetric error correction model under the MTAR specification is presented in Table 5.

With the MTAR model, the speed of adjustment is very high when it is positive and the correction back to equilibrium is about $62 \%$. The adjustment back to equilibrium is only $30 \%$ when it is negative. In addition, the results show that agricultural budgetary allocation has positive but insignificant relationship with agricultural output. The non-significant of this is not-unconnected with the low agricultural budgetary allocation to the agricultural sector. The coefficient of interest rate is negative and significant. This suggests that a 1 unit increase in interest rate will lead to 35 per cent fall in agricultural output, that is if the monetary authorities decides to increase the interest rate by 1 per cent, agricultural output will fall and thus any 
increase in interest rate will discourage investment in the agricultural sector, while a decrease in interest rate suggest that agricultural output will increase. In addition, real exchange rate has positive significant relationship with agricultural output. Also, inflation rate has a positive significant relationship with agricultural output. Thus, a unit increase in inflation rate will lead to about 22 per cent increase in agricultural output. The implication of this result is that when there is increases in the price level, agricultural output will increase, this suggest that during this period farmers will want to increase their output because of the increases in price. Lastly, institutional quality has a positive but insignificant relationship with agricultural output. The positive coefficient of institutional quality suggests that Nigeria institutions do impact positively of agricultural output.

Table 5. Non-Linear Error Correction Models, author's

\begin{tabular}{|l|c|c|c|c|}
\hline Variable & Coefficient & Standard Error & t-test & Prob \\
\hline$\rho_{11}$ & -0.617 & 0.107 & $-5.792^{* * *}$ & 0.000 \\
\hline$\rho_{12}$ & -0.303 & 0.086 & $-3.503^{* * *}$ & 0.005 \\
\hline$\Delta$ LAGDP(-1) & 0.739 & 0.225 & $3.278^{* *}$ & 0.014 \\
\hline$\Delta$ LAGRICBA(-1) & 0.358 & 0.573 & 0.625 & 0.184 \\
\hline$\Delta$ INTR(-1) & -0.346 & 0.158 & $-2.193^{* *}$ & 0.042 \\
\hline$\Delta$ LEXR(-1) & 1.159 & 0.561 & $2.067^{*}$ & 0.056 \\
\hline$\Delta$ INFR(-1) & 0.215 & 0.064 & $3.374^{* *}$ & 0.011 \\
\hline$\Delta$ INST(-1) & 0.763 & 0.488 & 1.562 & 0.113 \\
\hline
\end{tabular}

Note: $\rho_{11}$ and $\rho_{12}$ are the error correction terms for negative and positive residuals respectively.*,**,*** designates significance at the $10 \%, 5 \%$ and $1 \%$ levels.

6. Conclusion. This study examines the impact of fiscal and monetary policies on agricultural output in Nigeria. It employed the asymmetric cointegration method and documented that macroeconomic policies have mixed impact on agricultural output in Nigeria over the years. Specifically, important monetary variables that drive agricultural output in Nigeria include interest rate, exchange rate and inflation rate while government budgetary provision for the agricultural sector is still abysmal low and far below the Maputo recommendation, thus its non-significance. Institutional quality was found to have a positive relationship with agricultural output in Nigeria; however, it does significantly influence agricultural output. The study therefore concludes that macroeconomic policies both monetary and fiscal are important drivers of agricultural performance in Nigeria and good institutional quality is key in achieving better performance in the agricultural sector in Nigeria. It is against this conclusion that the study recommends that institutional quality need to be strengthen in Nigeria as this may go a long way to assist macroeconomic policies which will engender better performance in the agricultural sector. The government may need to show more political will to meet up with the Maputo (10\%) requirement in terms of budgetary provision for the agricultural sector.

Ahmad, H. A., \& Aworinde, O. B. (2016). The Role of Structural Breaks, Nonlinearity and Asymmetric Adjustments in African Bilateral Real Exchange Rates, International Review of Economics and Finance, 45, 144-159.

Ahmad, A. H., Harvey, D. I., \& Pentecost, E. J. (2011). Exchange rate regime verification: An alternative method of testing for regime changes, Economics Letters, 113(1), 96-98. 
Akhand Akhtar Hossain (2009) Macroeconomic Policies and Agricultural Terms of Trade, Bangladesh, 1952-2005, Journal of Contemporary Asia, 39(2), 204-230.

Alesina, A., \& Ardagna, A., Perotti, A., \& Schiantarelli, F. (2002). Fiscal Policy, Profits, and Investment, American Economic Review, 92(3), 571-589.

Alesina, Alberto, Silvia Ardagna, Roberto Perotti, and Fabio Schiantarelli. (2002) Fiscal policy, profits, and investment. American Economic Review, 92(3), 571-589.

Alagh, Munish. (2013) Positive and Normative Aspects of Food Policy and the Market in Indian Agriculture-An Empirical Analysis of Government Policy Interventions in Food Management. IIMA Working Papers WP2013-01-01, Indian Institute of Management Ahmedabad, Research and Publication Department. https://ideas.repec.org/p/iim/iimawp/11471.html

Asfaha, T. A., \& Jooste, A. (2007). The agricultural input elasticity of rural urban migration in South Africa. Agrekon, 45(1), 89- 105.

Baek, J., \& Koo W. W. (2010). The U.S. Agricultural Sector and the Macro economy. Journal of Agricultural and Applied Economics, 42, 3457-3465.

Balke, N. S., \& Thomas B. F. (1997). Threshold Cointegration, International Economic Review, 38(3), 627-645.

Barbhart, S. W. (1989). The effect of macroeconomic announcements on commodity prices. American Journal of Agricultural Economics, 71, 389-403.

Benetrix , A., \& Philip, R. L. (2009). The impact of Fiscal shocks on the Irish Economy. The institute for International studies, Discussion paper series iiidp281IIIS

Bessler, D. A. (1984). An Analysis of Dynamic Economic Relationships: An Application to the U.S.

Hog Market. Canadian Journal of Agricultural Economics, 32, 109-124.

Bruce, G. (1985). Macroeconomics and The Agricultural Sector, Bulletin of Indonesian Economic Studies, 21(2), 51-73.

Chambers R. G. (1984). Agricultural and financial market interdependence in the short run. American Journal of Agricultural Economics, 66, 12-24.

Chan, K. S. (1993). Consistency and Limiting Distribution of the Least Squares Estimator of Threshold Autoregressive Model, The Annals of Statistics, 21, 520-533.

Chebbi, H. E., \& Marcelo, O. (2011). Agricultural Trade Balance and ExchangeRate Depreciation:

The Case of Tunisia, the Economic Research Forum (ERF) 21 Al-Sad Al-Aaly Street Dokki, Giza Egypt Devadoss, S \& Meyers WH (1987). Relative prices and money: further results for the United States.

American Journal of Agricultural Economics, 69, 838-842.

Dickey, D. A., \& Fuller, W. A. (1979). Distributions of the Estimators for Autoregressive Time Series with a Unit Root', Journal of the American Statistical Association, 74, 427-431.

Dushmanitch, V. Y., \& Darroch, M. A. G. (1990). An Economic Analysis of the Impacts of Monetary Policy on South African Agriculture Agrekon, 29, 267-321.

Enders, W., \& Siklos, P. L., (2001). Cointegration and Threshold Adjustment, Journal of Business \& Economic Statistics, 19(2), 166-176.

Engle, R. F., \& Granger, C. W. J. (1987). Co-integration and Error Correction: Representation, Estimation, and Testing', Econometrica, 55(2), 251-276.

Fadeyi, O. A., Ogundeji, A. A., \& Willemse, B. J. (2014). Establishing the linkages between the South African agricultural trade balance and macroeconomic indicators, Agrekon, 53(4), 92-105.

Ginn, W., Pourroy, M., (2018) Optimal monetary policy in the presence of food price subsidies, Economic Modelling, https://doi.org/10.1016/j.econmod.2018.06.012

Kargbo M. (2007) The effects of macroeconomic factors on South African agriculture, Applied Economics, 39(17), 2211-2230.

Lee, J., \& Strazicich, M. C. (2003). Minimum Lagrange Multiplier Unit Root Test with Two Structural Breaks. The Review of Economics and Statistics, 85(4), 1082-1089.

Muroyiwa, B., Sitima, I., Sibanda, K., \& Mushunje, A. (2014). Monetary Policy Actions and Agricultural Sector Outcomes: Empirical Evidence from South Africa. Mediterranean Journal of Social Sciences, 5(1), 613 .

Dawson, N, P., \& Lingard, J. (2003) Macroeconomic Impacts on Bulgarian Agriculture during Transition, Applied Economics, 35(7), 817-823.

$\mathrm{Ng}, \mathrm{S}$., \& Perron, P. (1995). Unit root tests in ARMA models with data dependent methods for the selection of the truncation lag. Journal of the American Statistical Association, 90, 268-281.

Ng, S., \& Perron, P. (2001). Lag length selection and the construction of unit root tests with good size and power, Econometrica, 69, 1529-1554. 
Nick, V. (2004). The influence of policy on the roles of agriculture in South Africa, Development Southern Africa, 21(1), 155-177.

Orden, D. (1986). Money and agriculture: the dynamics of money-financial market-agricultural trade linkages. Agricultural Economics Research, 38(3), 14- 28.

Orden, D., \& Fackler, P. (1989). Identifying monetary impacts on agricultural prices in VAR models. American Journal of Agricultural Economics, 71, 495-502.

Perron, P. (1989). The Great Crash, the Oil Price Shock, and the Unit Root Hypothesis. Econometrica 57(6), 1361-1401.

Petrucelli, J., \& Woolford, S. (1984). A Threshold AR(1) Model, Journal of Applied Probability, 21, $270-286$.

Robertson, J. C. \& Orden, D. (1990). Monetary impacts on prices in the short and long run: some evidence from New Zealand. American Journal of Agricultural Economics, 72, 160-171.

Schuh, G. E, (1974). The Exchange Rate and U. S. Agriculture, American Journal of Agricultural Economics, 56(1), 1-13.

Shei, Shun-Yi \& Thompson, R. L. (1978). The Short Run Welfare Effects Of Export Controls Canadian Journal Of Agricultural Economics, https://doi.org/10.1111/j.1744-7976.1978.tb02897.x

Starleaf, D. R. (1982). Macroeconomic policies and their impact upon the farm sector. American Journal of Agricultural Economics, 64, 854-60.

Tweeten LG (1980). Macroeconomics in Crisis: Agriculture in an underachieving economy. American Journal of Agricultural Economics, 62, 853-865.

Fйnyes T. I. \&. Meyer N. G (1998). agricultural policy and Macroeconomic issues in South Africa. Agrekon, 37(1), 63-85.

Wane, A Gilbert, S \& Dibooglu, S (2004). Critical values of the empirical F-distribution for threshold autoregressive and momentum threshold autoregressive models, 2004 Discussion Papers for the Department of Economics, Southern Illinois University at Carbondale.

Ahmad, H. A., \& Aworinde, O. B. (2016). The Role of Structural Breaks, Nonlinearity and Asymmetric Adjustments in African Bilateral Real Exchange Rates, International Review of Economics and Finance, 45, 144-159.

Ahmad, A. H., Harvey, D. I., \& Pentecost, E. J. (2011). Exchange rate regime verification: An alternative method of testing for regime changes, Economics Letters, 113(1), 96-98.

Akhand Akhtar Hossain (2009) Macroeconomic Policies and Agricultural Terms of Trade, Bangladesh, 1952-2005, Journal of Contemporary Asia, 39(2), 204-230.

Alesina, A., \& Ardagna, A., Perotti, A., \& Schiantarelli, F. (2002). Fiscal Policy, Profits, and Investment, American Economic Review, 92(3), 571-589.

Alesina, Alberto, Silvia Ardagna, Roberto Perotti, and Fabio Schiantarelli. (2002) Fiscal policy, profits, and investment. American Economic Review, 92(3), 571-589.

Alagh, Munish. (2013) Positive and Normative Aspects of Food Policy and the Market in Indian Agriculture-An Empirical Analysis of Government Policy Interventions in Food Management. IIMA Working Papers WP2013-01-01, Indian Institute of Management Ahmedabad, Research and Publication Department. https://ideas.repec.org/p/iim/iimawp/11471.html

Asfaha, T. A., \& Jooste, A. (2007). The agricultural input elasticity of rural urban migration in South Africa. Agrekon, 45(1), 89- 105.

Baek, J., \& Koo W. W. (2010). The U.S. Agricultural Sector and the Macro economy. Journal of Agricultural and Applied Economics, 42, 3457-3465.

Balke, N. S., \& Thomas B. F. (1997). Threshold Cointegration, International Economic Review, 38(3), 627-645.

Barbhart, S. W. (1989). The effect of macroeconomic announcements on commodity prices. American Journal of Agricultural Economics, 71, 389-403.

Benetrix , A., \& Philip, R. L. (2009). The impact of Fiscal shocks on the Irish Economy. The institute for International studies, Discussion paper series iiidp281IIIS

Bessler, D. A. (1984). An Analysis of Dynamic Economic Relationships: An Application to the U.S.

Hog Market. Canadian Journal of Agricultural Economics, 32, 109-124.

Bruce, G. (1985). Macroeconomics and The Agricultural Sector, Bulletin of Indonesian Economic Studies, 21(2), 51-73.

Chambers R. G. (1984). Agricultural and financial market interdependence in the short run. American Journal of Agricultural Economics, 66, 12-24. 
Chan, K. S. (1993). Consistency and Limiting Distribution of the Least Squares Estimator of Threshold Autoregressive Model, The Annals of Statistics, 21, 520-533.

Chebbi, H. E., \& Marcelo, O. (2011). Agricultural Trade Balance and ExchangeRate Depreciation: The Case of Tunisia, the Economic Research Forum (ERF) 21 Al-Sad Al-Aaly Street Dokki, Giza Egypt Devadoss, S \& Meyers WH (1987). Relative prices and money: further results for the United States.

American Journal of Agricultural Economics, 69, 838-842.

Dickey, D. A., \& Fuller, W. A. (1979). Distributions of the Estimators for Autoregressive Time Series with a Unit Root', Journal of the American Statistical Association, 74, 427-431.

Dushmanitch, V. Y., \& Darroch, M. A. G. (1990). An Economic Analysis of the Impacts of Monetary Policy on South African Agriculture Agrekon, 29, 267-321.

Enders, W., \& Siklos, P. L., (2001). Cointegration and Threshold Adjustment, Journal of Business \& Economic Statistics, 19(2), 166-176.

Engle, R. F., \& Granger, C. W. J. (1987). Co-integration and Error Correction: Representation, Estimation, and Testing', Econometrica, 55(2), 251-276.

Fadeyi, O. A., Ogundeji, A. A., \& Willemse, B. J. (2014). Establishing the linkages between the South African agricultural trade balance and macroeconomic indicators, Agrekon, 53(4), 92-105.

Ginn, W., Pourroy, M., (2018) Optimal monetary policy in the presence of food price subsidies, Economic Modelling, https://doi.org/10.1016/j.econmod.2018.06.012

Kargbo M. (2007) The effects of macroeconomic factors on South African agriculture, Applied Economics, 39(17), 2211-2230.

Lee, J., \& Strazicich, M. C. (2003). Minimum Lagrange Multiplier Unit Root Test with Two Structural Breaks. The Review of Economics and Statistics, 85(4), 1082-1089.

Muroyiwa, B., Sitima, I., Sibanda, K., \& Mushunje, A. (2014). Monetary Policy Actions and Agricultural Sector Outcomes: Empirical Evidence from South Africa. Mediterranean Journal of Social Sciences, 5(1), 613.

Dawson, N, P., \& Lingard, J. (2003) Macroeconomic Impacts on Bulgarian Agriculture during Transition, Applied Economics, 35(7), 817-823.

$\mathrm{Ng}, \mathrm{S}$., \& Perron, P. (1995). Unit root tests in ARMA models with data dependent methods for the selection of the truncation lag. Journal of the American Statistical Association, 90, 268-281.

Ng, S., \& Perron, P. (2001). Lag length selection and the construction of unit root tests with good size and power, Econometrica, 69, 1529-1554.

Nick, V. (2004). The influence of policy on the roles of agriculture in South Africa, Development Southern Africa, 21(1), 155-177.

Orden, D. (1986). Money and agriculture: the dynamics of money-financial market-agricultural trade linkages. Agricultural Economics Research, 38(3), 14- 28.

Orden, D., \& Fackler, P. (1989). Identifying monetary impacts on agricultural prices in VAR models. American Journal of Agricultural Economics, 71, 495-502.

Perron, P. (1989). The Great Crash, the Oil Price Shock, and the Unit Root Hypothesis. Econometrica 57(6), 1361-1401. 270-286

Petrucelli, J., \& Woolford, S. (1984). A Threshold AR(1) Model, Journal of Applied Probability, 21,

Robertson, J. C. \& Orden, D. (1990). Monetary impacts on prices in the short and long run: some evidence from New Zealand. American Journal of Agricultural Economics, 72, 160-171.

Schuh, G. E, (1974). The Exchange Rate and U. S. Agriculture, American Journal of Agricultural Economics, 56(1), 1-13.

Shei, Shun-Yi \& Thompson, R. L. (1978). The Short Run Welfare Effects Of Export Controls Canadian Journal Of Agricultural Economics, https://doi.org/10.1111/j.1744-7976.1978.tb02897.x

Starleaf, D. R. (1982). Macroeconomic policies and their impact upon the farm sector. American Journal of Agricultural Economics, 64, 854-60.

Tweeten LG (1980). Macroeconomics in Crisis: Agriculture in an underachieving economy. American Journal of Agricultural Economics, 62, 853-865.

Fŭnyes T. I. \&. Meyer N. G (1998). agricultural policy and Macroeconomic issues in South Africa. Agrekon, 37(1), 63-85.

Wane, A Gilbert, S \& Dibooglu, S (2004). Critical values of the empirical F-distribution for threshold autoregressive and momentum threshold autoregressive models, 2004 Discussion Papers for the Department of Economics, Southern Illinois University at Carbondale. 